Original Research Paper

\title{
Analysis of Land Use and Land Cover Changing Patterns of Bangladesh Using Remote Sensing Technology
}

\author{
${ }^{1}$ Md. Mahmudul Hasan, ${ }^{2}$ Rashidul Islam, ${ }^{3}$ Md. Saifur Rahman, ${ }^{4}$ Md. Ibrahim, \\ ${ }^{5}$ Md. Shamsuzzoha, ${ }^{6}$ Ruma Khanam and ${ }^{7}$ A. K. M. Mostafa Zaman \\ ${ }^{I}$ Department of Geo-Information Science and Earth Observation, Faculty of Environmental Science and Disaster Management, \\ Patuakhali Science and Technology University, Dumki, Patuakhali-8602, Bangladesh \\ ${ }^{2}$ Faculty of Environmental Science and Disaster Management, Patuakhali Science and Technology University, \\ Dumki, Patuakhali-8602, Bangladesh \\ ${ }^{3}$ Geo-Information Science and Earth Observation, Faculty of Environmental Science and Disaster Management, \\ Patuakhali Science and Technology University, Dumki, Patuakhali-8602, Bangladesh \\ ${ }^{4}$ Geo-Information Science and Earth Observation, Faculty of Disaster Management, Patuakhali Science and Technology \\ University, Dumki, Patuakhali-8602, Bangladesh \\ ${ }^{5}$ Department of Emergency Management, Faculty of Environmental Science and Disaster Management, \\ Patuakhali Science and Technology University, Dumki, Patuakhali-8602, Bangladesh \\ ${ }^{6}$ Department of Disaster Resilience and Engineering, Faculty of Disaster Management, Patuakhali Science and Technology \\ University, Dumki, Patuakhali-8602, Bangladesh \\ ${ }^{7}$ Department of Agronomy, Faculty of Agriculture, Patuakhali Science and Technology University, \\ Dumki, Patuakhali-8602, Bangladesh
}

Article history

Received: 25-03-2021

Revised: 19-06-2021

Accepted: 08-07-2021

Corresponding Author: Md. Mahmudul Hasan Department of GeoInformation Science and Earth Observation, Faculty of Environmental Science and Disaster Management, Patuakhali Science and Technology University, Dumki, Patuakhali-8602, Bangladesh Email: mahmudgeo@pstu.ac.bd
Abstract: Bangladesh is a deltaic country situated in the fringe of Bay of Bengal. Land Use and Land Cover (LULC) change is the concerning issue in the present world. Bangladesh is highly vulnerable to LULC changes due to its geographical location and shortage of awareness that's why author conduct this research. The research was focused on analysing the LULC changes pattern of Bangladesh from the years 1990 to 2019 over the last three decades. Total 42 image datasets were used in this study collected from the Landsat Thematic Mapper (TM) 4-5 C 1 level-1 and Landsat 8 (OLI_TIRS) satellite. LULC map for the selected years has been worked out by supervised classification with maximum likelihood algorithm and multi-sectoral supervised classification algorithm to Landsat sensor data. Extract by mask tools was used for cutting the desired location and then exercised tool for image classification with different band combination such as $(2,3,4)(1,2,3)$ $(2,4,7)(3,4,5)(3,5,7)$. Method used for area calculation is; (Counted pixels)* (pixel size $)^{2 / 1000000(m) . ~ R e s e a r c h ~ f o u n d ~ t h a t ~ m a j o r ~ c h a n g e s ~}$ happened in urban area, forest, water body and vegetation cover. Here, water body and forest area has decreased; and it was 9.20 and $3.86 \%$ of total area. After 29 years $5.18 \%$ land had changed to urban area, which is $6.27 \%$ of total area and vegetation cover had increased $3.36 \%$. Land cover of Bangladesh is continually changed for overpopulation; damaging water body and forest for unsuited urbanization. Study concludes that 29 years analysis of LULC trend of Bangladesh will help to understand and take necessary action to the line departments to reduce the impact of land use and land cover change as well as provide the changing scenario of LULC all over the country which will be helps to appropriate land use planning and management of Bangladesh.

Keywords: Land Use, Land Cover, LULC Change Analysis, Supervised Classification, GIS and RS, Bangladesh 


\section{Introduction}

The Land Use and Land Cover (LULC) pattern and change detection assessment are concerned of scientists worldwide for realizing the importance of the land resource to achieve environmental security and sustainable development (Xiubin, 1996). At present, the LULC pattern's changing scenario has become an immense issue for utilizing our natural capital and resources. Here, land use refers to human activity on the earth's surface such as infrastructure building, agricultural cropping and land cover refers to natural or manmade physical properties of the earth surface such as waterbody, vegetation covers etc. LULC has changed expeditiously for urbanization and overpopulation (Sikarwar and Chattopadhyay, 2016; Riggio et al., 2018). This is immense truth for unplanned, changing areas like urban settlements in developing countries (López et al., 2001; Jain et al., 2013). To better understand the impact of LULC change on earth surface area need to analyse the trend of land cover change near about the previous 30 years and predict the chance of future changes of land use (Ojima et al., 1994).

Satellite images are the most common data source for mapping LULC formation (El-Kawy et al., 2011). Satellite image provides the geo-referenced raw pictures (Leprince et al., 2007). Thematic Mapper (TM) imagery is used for land cover mapping (Aplin et al., 1999). The changes in the land cover of the study area are analysed by land cover map using satellite images (Weng, 2002). By using multi-date images, it is possible to changed detection and also monitors and evaluates the use of land cover due to human actions and natural conditions (Yang and Lo, 2002). In this study author used Landsat 5 (TM) and Landsat 8 (OLI_TIRS) satellite images from 1990-2019. For monitoring the changing pattern study create LULC map for the selected years by using the method of supervised classification with maximum likelihood algorithm, multi-sectoral supervised classification algorithm to Landsat sensor data and extract by mask tools. Accuracy measurement work are done to validate the research findings and the result is acceptable level.

Bangladesh is a developing and densely populated country (Cuervo-Cazurra and Genc, 2008), in this country, 834 persons are living per square kilometre (Faisal and Parveen, 2004). Due to high population density, this country's total land area is continually changed including losses of vast agricultural lands (Hossain et al., 2020), waterbodies and forest areas for urban growth and development. Therefore, it is essential to update the present LULC status of the country for proper land use planning, land management and sustainable development at rural, urban and regional level. According to above statements author choose the study area and conduct this research and analyze near about 30 (thirty) years LULC to find out the LULC changes pattern of Bangladesh.

\section{Materials and Methods}

\section{Study Area}

Bangladesh, occupying an area of $147,570 \mathrm{~km}^{2}$, is located in the eastern Himalayan region of South Asia between $20^{\circ} 34^{\prime}$ to $26^{\circ} 38^{\prime}$ north latitudes and $88^{\circ} 01^{\prime}$ to $92^{\circ} 42^{\prime}$ east longitudes (Fig. 1). It is surrounded on three sides predominantly by India, only the South being open to the Bay of Bengal.

\section{Datasets}

The data used in this study included 14 Landsat Thematic Mapper (TM) 4-5 C1 level-1 satellite images for each year such as 1990, 2000, 2010 and Landsat 8 OLI/TIRS C1 Level-1 Images for 2019 (Table 1). The image data were freely accessed from the Landsat archive of the United States Geological Survey (USGS) website (https://glovis.usgs.gov/) (https://earthexplorer.usgs.gov/) (Chavez et al., 1991; Gutman et al., 2008). Here satellite image data were used for the land use and land cover classification (Tucker et al., 1985).

\section{Data Preparation}

Four LULC maps were worked out by using of the supervised classification method with maximum likelihood algorithm (Rawat and Kumar, 2015). Land cover map for the selected years are generated by applying a multi-sectoral supervised classification algorithm to Landsat sensor data (Lucas et al., 2007). Landsat 5 (TM) and Landsat 8 (OLI_TIRS) satellite images have seven and eleven bands respectively which were converted to an image by using composite bands (Zha et al., 2003). For supervised classification firstly needed to finish the processing of basic methods like composite band, copy raster, remove clouds and mosaic to new raster, extract by mask and maximum likelihood images classification (Su et al., 2010). The whole processes were finishing by ArcMap 10.8® software Fig. 2.

The copy raster features were removed the background of images with rendering a transparent background. This section was pre-processing for image classification. Haze reduction was performed in this section. For this study image enhancement technique has preferred for histogram equalization. Cloud cover and haze condition were acceptable because it's zero in all images. In the study, the image mosaic to new raster using ArcMap 10.8® software was created from the Landsat images to develop one accurate aerial representation of the study area (Hood and Bayley, 2008). The extract by mask tool was used for cutting the desired location (Magesh and Ch, 2012; Ramírez-Villegas and Bueno Cabrera 2009). 


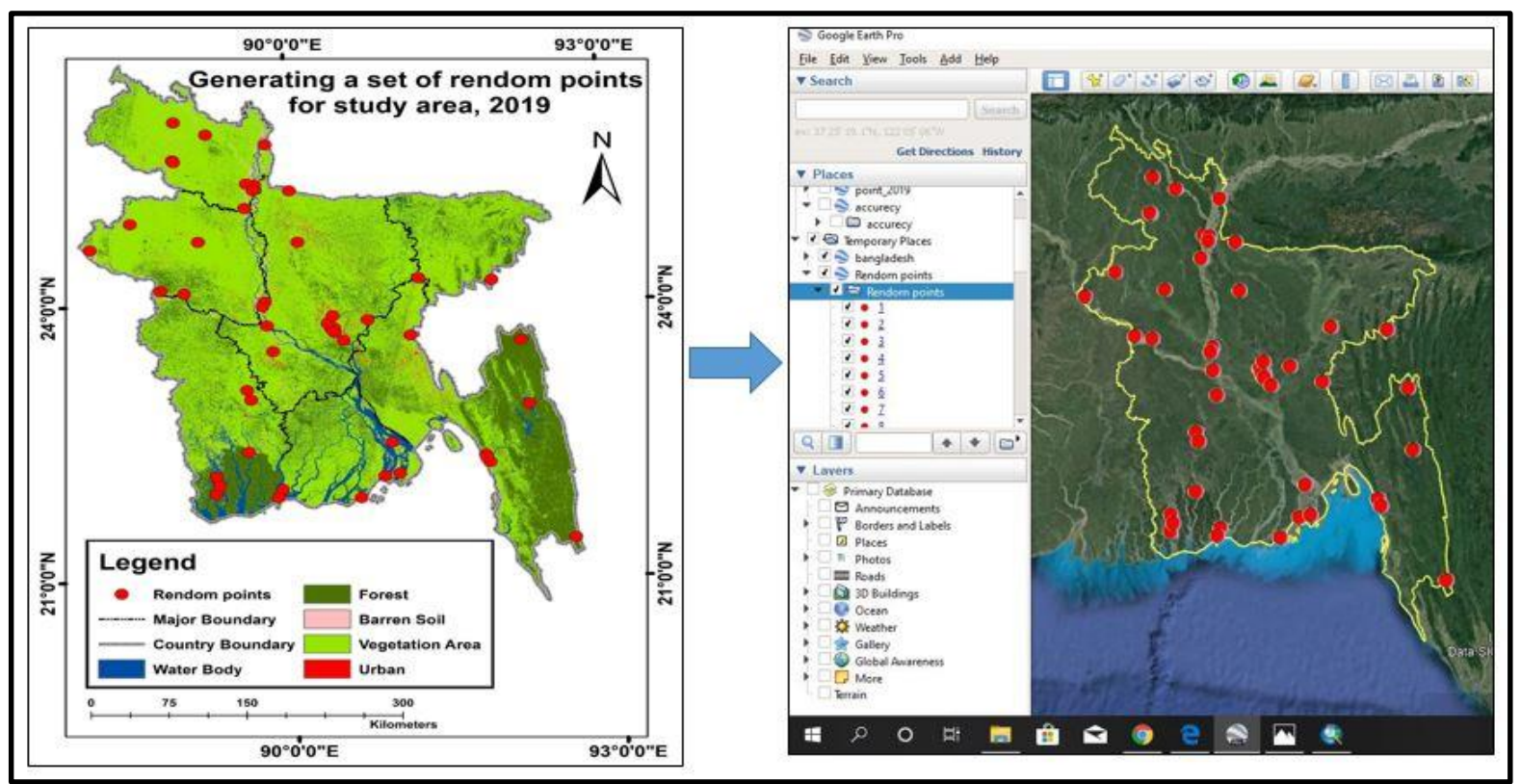

Fig. 1: Study area (Generating random points for accuracy assessment of classified image; Source: Author)

Table 1: Characteristics of the collected Landsat data

\begin{tabular}{llll}
\hline Acquisition date & Satellite (Sensor) & Resolution $(\mathrm{m})$ & Cloud cover $(\%)$ \\
\hline $07-01-1990$ & Landsat 5 (TM) & 30 & 0 \\
$19-01-2020$ & Landsat 5 (TM) & 30 & 0 \\
$30-01-2010$ & Landsat 5 (TM) & 30 & 0 \\
$24-01-2019$ & Landsat 8 (OLI_TIRS) & 30 & 0 \\
\hline
\end{tabular}

\section{Classification}

In this study, images were classified into five major classes; water body, forest, urban area, barren soil and vegetation cover. The study was used the standard "false color "composite for Landsat 5 TM satellite images which include 7, 4, 2 bands. This combination provides a "natural-like" rendition. Healthy vegetation was bright green, grasslands were appeared green, pink areas represent barren soil, oranges and browns represent sparsely vegetated areas, water was blue and urban areas appear in varying shades of magenta (Crosta and Moore, 1989; Tamouk et al., 2013; Dwivedi and Rao, 1992).

Natural color $(4,3,2)$ were used for Landsat $8 \mathrm{TM}$ false-color composite which repeats near what one human eye sees. Where sound vegetation was green, unfortunate greenery was darker. Urban highlights seem white and dim and water was dull blue or dark (Elhag, 2017; Mwaniki et al., 2015; Tamouk et al., 2013; Dwivedi and Rao, 1992). To train for selecting each land use and land cover categories a significant number of pixels were selected in this study. About 350 training data sets for each class have been created and the minimum allowance distance set was $30 \mathrm{~m}$. Finally, the maximum likelihood supervised images classification method was applied by using ArcGIS software. In this research, area calculation was done by following Eq. 1 (Eva et al., 2004):
Area $=\frac{(\text { counted pixels }) \times(\text { pixel size })^{2}}{10^{6}}$

\section{Post-Classification Change Detection}

In this study for processing, analyzing and detecting change of those classified images Arc GIS 10.8®, Google Earth Pro and SPSS software's were used successfully. Finally, area differences with ten years' interval were calculated to find out the LULCC from 1990 to 2019.

\section{Accuracy Assessment}

Accuracy assessment was assessed care of matrix using user accuracy, producer accuracy and overall accuracy and Kappa Coefficient. About 150 random points were created and the minimum allowance distance set was $30 \mathrm{~m}$ for each class. They were measured using Eq. 2, 3 and 4.

User accuracy was measured using Eq. 2 (Tilahun and Teferie, 2015):

User Accuracy $=\frac{\text { number of correct points }(\text { value })}{\text { The rowtotal }(\text { value })} \times 100$ 
Producer accuracy was measured using Eq. 3 (Tilahun and Teferie, 2015):

Producer Accuracy $=\frac{\text { Number of correct points }(\text { value })}{\text { The column total }(\text { value })} \times 100$

Overall accuracy was measured using Eq. 4 (Tilahun and Teferie, 2015):

Overall Accuracy $=\frac{\text { Number of total correct points }(\text { value })}{\text { The number of points }(\text { value })} \times 100$

The Kappa Coefficient equation was used as a measure of agreement between model predictions and reality (Congalton, 1991) or to ascertain if the values comprised in an error matrix represent a result significantly better than random (Jensen and Cowen, 1999). The applied Kappa coefficient values were calculated using by following Eq. 5 (Tilahun and Teferie, 2015; Congalton, 1991):

$K=\frac{N \sum_{i=1}^{n} x_{i i}-\sum_{i=1}^{r}\left(x_{i+} \times x_{+i}\right)}{N^{2}-\sum_{i=1}^{r}\left(x_{i i} \times x_{+i}\right)} \times 100$

\section{Results}

Applying maximum likelihood and multi-sectoral supervised classification algorithm LULC map from the years of 1990 - 2019 is given with ten years' interval Fig. 3 respectively. In 1990, waterbody was $12.51 \%$ of the total area. After ten years, this waterbody has decreased almost $1.45 \%$ in 2000 and in the next ten years' waterbody has decreased almost $1.85 \%$. Next, nine years' waterbody had also decreased and it was $9.20 \%$ from the total area Table 2 and Fig. 3. Forest had decreased by $3.86 \%$ from 1990 to 2019. First ten years, it had $0.61 \%$ but in the next nineteen years, it had decreased almost 3.25\% Table 2 and Fig. 3. On the other side urban area had increased fast; the urban area was only $1.09 \%$ of the total area in 1990. After ten years in 2000 , it had $2.93 \%$ where almost $1.84 \%$ had increased. Next ten years it had increased $2.38 \%$ and next nine years it had increased $0.96 \%$; that was $6.27 \%$ from total area. Almost 5.18\% land had changed to urban after 29 years Table 2 and Fig. 3. Barren soil is almost same after 29 years; it has changed $0.26 \%$ Table 2 and Fig. 3.

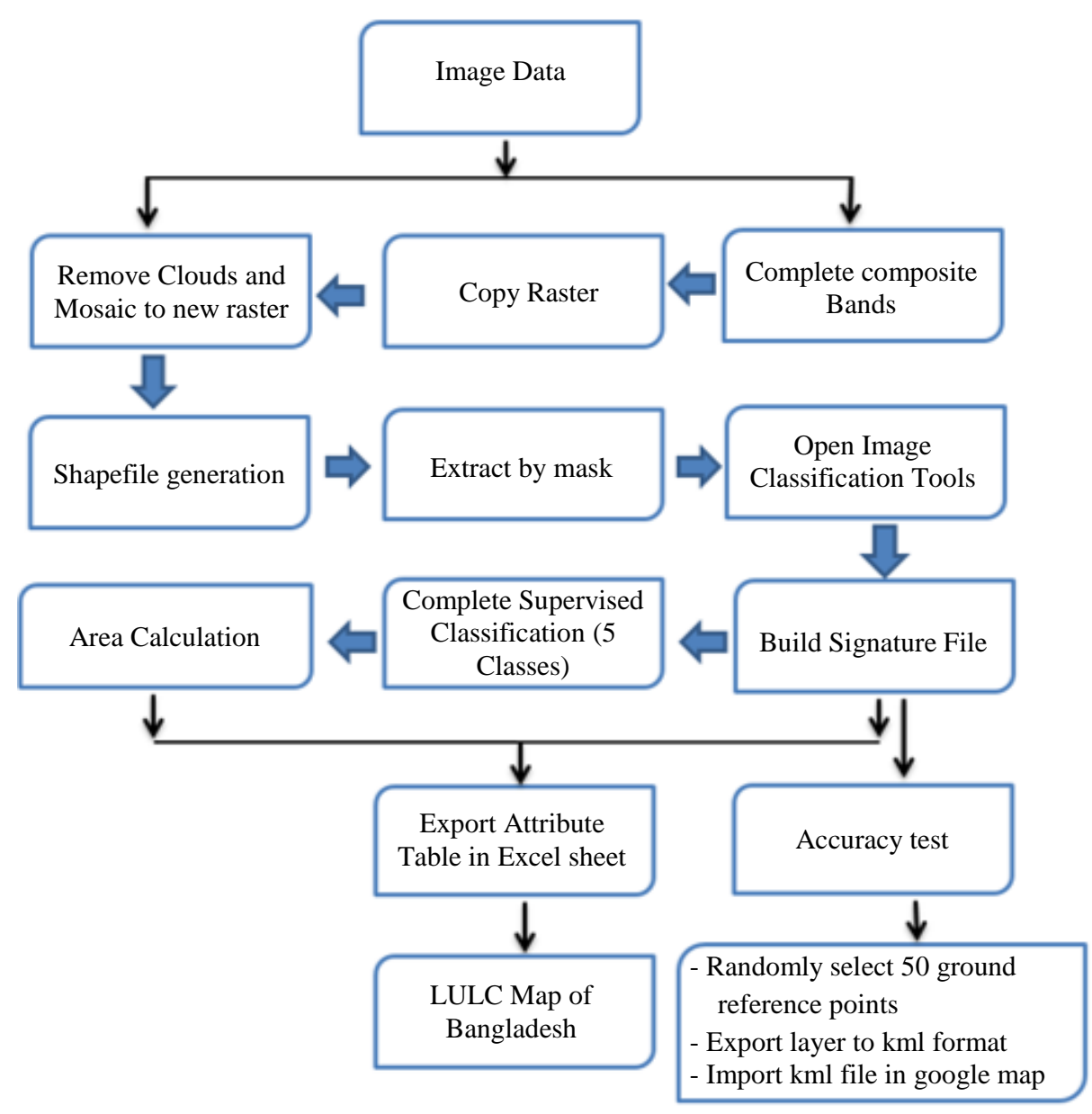

Fig. 2: Methodological framework of the study 

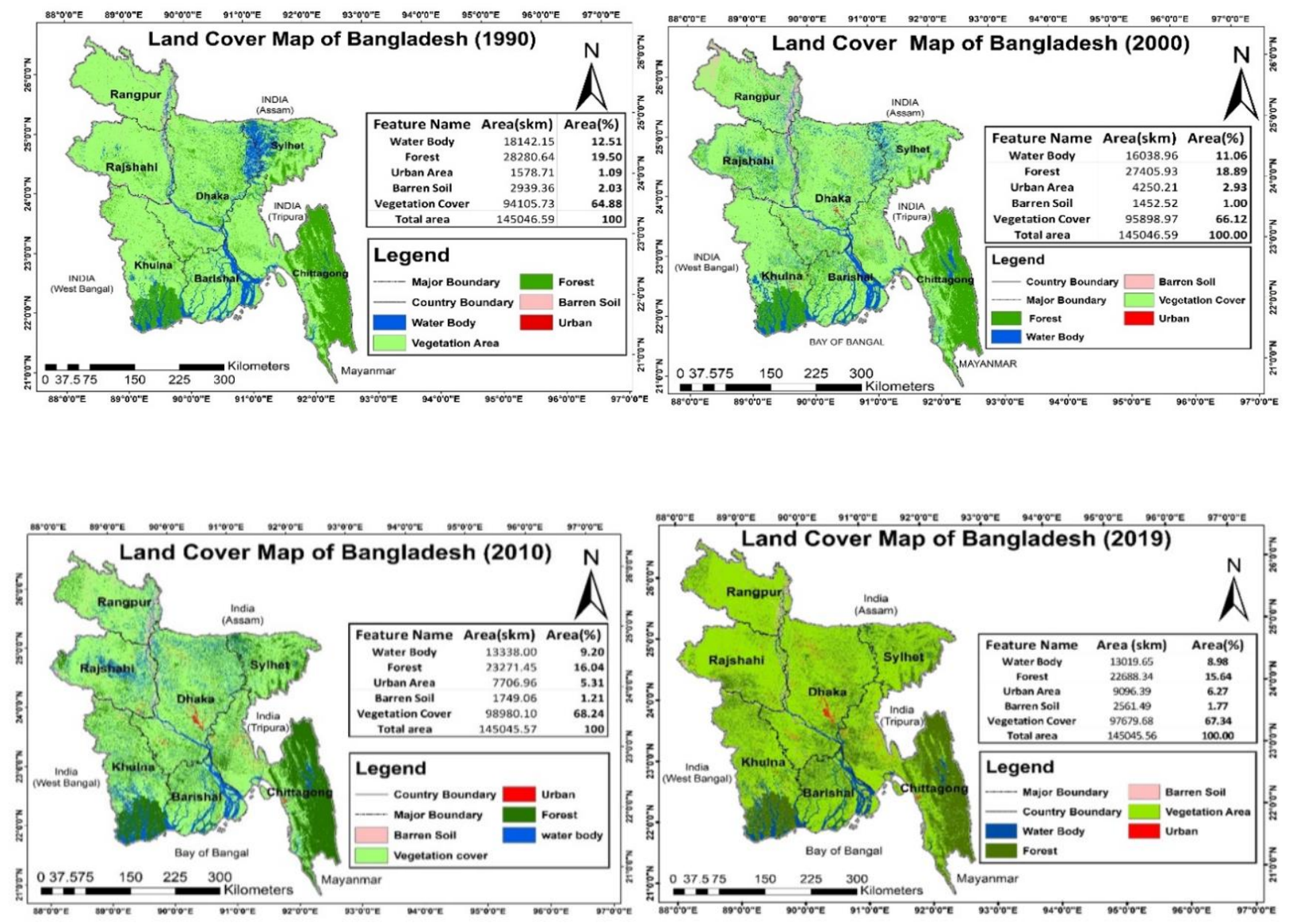

Fig. 3: LULC map of Bangladesh (1990-2019)

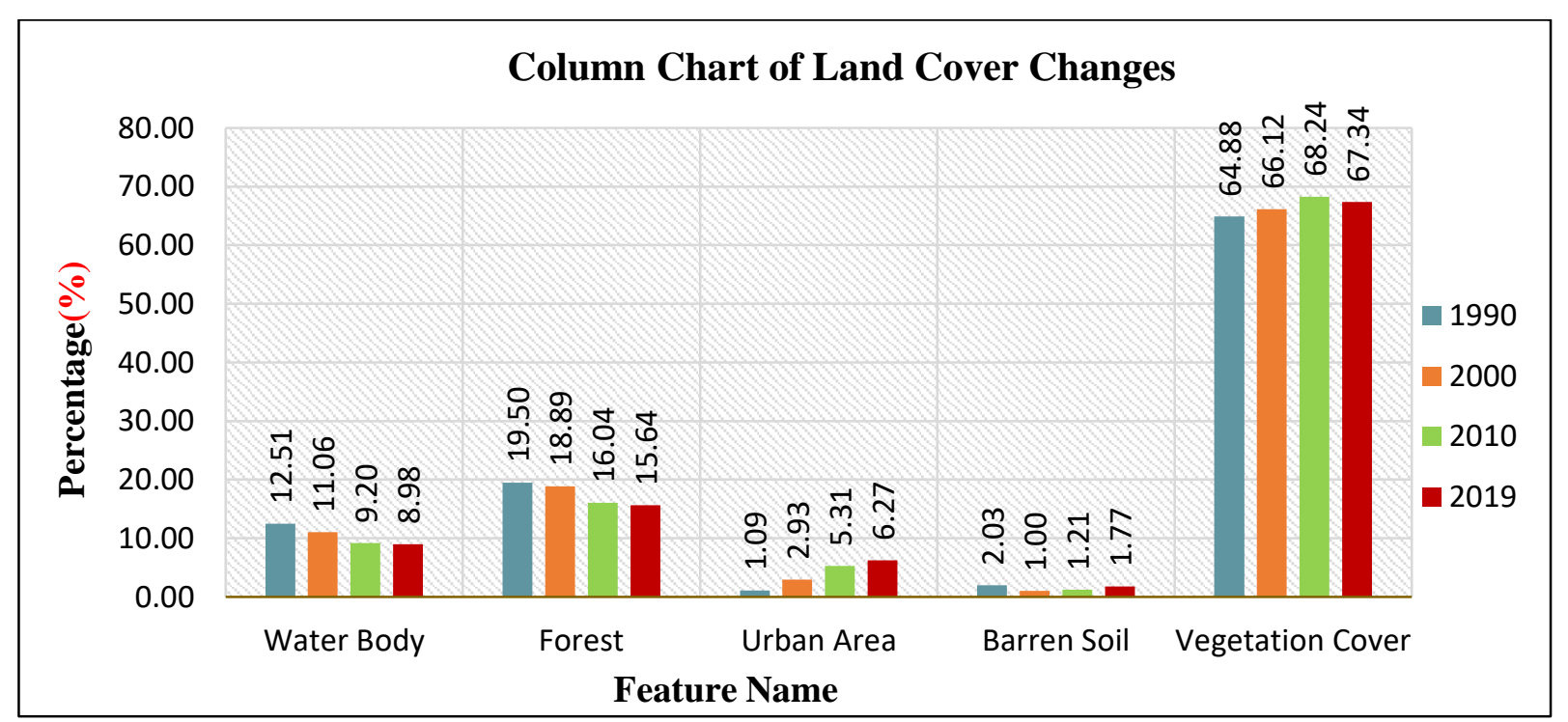

Fig. 4: LULC change status over ten years' intervals in Bangladesh 
Table 2: LULC changes data from 1990 to 2019

\begin{tabular}{|c|c|c|c|c|c|c|c|c|}
\hline \multirow[b]{2}{*}{ Name of feature } & \multicolumn{2}{|l|}{1990} & \multicolumn{2}{|l|}{2000} & \multicolumn{2}{|l|}{2010} & \multicolumn{2}{|l|}{2019} \\
\hline & Area $\left(\mathrm{Km}^{2}\right)$ & Area $(\%)$ & Area $\left(\mathrm{Km}^{2}\right)$ & Area $(\%)$ & Area $\left(\mathrm{Km}^{2}\right)$ & Area $(\%)$ & Area $\left(\mathrm{Km}^{2}\right)$ & Area $(\%)$ \\
\hline Waterbody & 18142.13 & 12.51 & 16038.96 & 11.06 & 13338.02 & 9.20 & 13019.65 & 8.98 \\
\hline Forest & 28280.64 & 19.50 & 27405.91 & 18.89 & 23271.45 & 16.04 & 22688.34 & 15.64 \\
\hline Urban Area & 1578.71 & 1.09 & 4250.21 & 2.93 & 7706.95 & 5.31 & 9096.39 & 6.27 \\
\hline Barren Soil & 2939.36 & 2.03 & 1452.52 & 1.00 & 1749.06 & 1.21 & 2561.49 & 1.77 \\
\hline Vegetation Cover & 94105.73 & 64.88 & 95898.97 & 66.12 & 98980.10 & 68.24 & 97679.69 & 67.34 \\
\hline Total area & 145046.57 & 100.00 & 145046.57 & 100.00 & 145046.57 & 100.00 & 145046.57 & 100.00 \\
\hline
\end{tabular}

Table 3: Accuracy measurement of the study period of 1990 to 2019; using user accuracy, producer accuracy, overall accuracy and kappa co-efficient methods

\begin{tabular}{|c|c|c|c|c|c|c|c|c|c|c|c|c|}
\hline \multirow[b]{2}{*}{ Year } & \multicolumn{5}{|c|}{ User accuracy (\%) } & \multicolumn{5}{|c|}{ Producer accuracy $(\%)$} & \multirow[b]{2}{*}{$\begin{array}{l}\text { Over all } \\
\text { accuracy }(\%)\end{array}$} & \multirow[b]{2}{*}{$\begin{array}{l}\text { Kappa co- } \\
\text { efficient }(\%)\end{array}$} \\
\hline & Waterbody & Forest & $\begin{array}{l}\text { Barren } \\
\text { soil }\end{array}$ & $\begin{array}{l}\text { Vegetation } \\
\text { area }\end{array}$ & Urban & Waterbody & Forest & $\begin{array}{l}\text { Barren } \\
\text { soil }\end{array}$ & $\begin{array}{l}\text { Vegetation } \\
\text { area }\end{array}$ & Urban & & \\
\hline 2000 & $90 \%$ & $100 \%$ & $80 \%$ & $100 \%$ & $90 \%$ & $81.8 \%$ & $100 \%$ & $88.9 \%$ & $83.3 \%$ & $90 \%$ & $92 \%$ & $90 \%$ \\
\hline 2010 & $90 \%$ & $80 \%$ & $90 \%$ & $100 \%$ & $80 \%$ & $90 \%$ & $88.9 \%$ & $90.9 \%$ & $76.9 \%$ & $100 \%$ & $88 \%$ & $85 \%$ \\
\hline 2019 & $100 \%$ & $100 \%$ & $90 \%$ & $90 \%$ & $90 \%$ & $90.9 \%$ & $90.9 \%$ & $100 \%$ & $90 \%$ & $90 \%$ & $94 \%$ & $92.5 \%$ \\
\hline
\end{tabular}

Vegetation cover had increased $3.36 \%$ after 29 years. In 1990 , it was $64.88 \%$ and 2010 it has $68.24 \%$ of total area. But the next nine years it has decreased $0.90 \%$ which is $67.34 \%$ from total area. Table 2 and Fig. 4 has showed for easily understood.

\section{Accuracy Measurement}

Accuracy assessment is a valuable step in the processing of remote sensing data. The actuality of the resulting data to a user is established by it (Fung and LeDrew, 1988). The errors of commission that illustrate the possibility of a classified pixel matching the land cover type of its similar real-world geographic location are measured by user accuracy. Producer's accuracy is measured errors of a gap, which is an assessment of how well real-world land cover types can be classified. The overall accuracy of the classified image is compared to how each of the pixels is classified against the demonstrated land cover established from their consisted ground truth data (Riggio and Ndambuki, 2017; Congalton, 1991; Unger Holtz, 2007).

User accuracy's and Producer's accuracy are calculated individually each type such as water body, urban area, vegetation area etc. using Eq. 2 and 3.

Example: In 1990, water body's correct points were 10 and row total and column total were also 10 :

$$
\begin{aligned}
& \text { User Accuracy }=\frac{\text { number of correct points }(\text { value })}{\text { The rowtotal }(\text { value })} \times 100 \\
& =\frac{9}{10} \times 100 \therefore \text { User Accuracy }=90 \% \\
& \text { Producer Accuracy }=\frac{\text { Number of correct points }(\text { value })}{\text { The columntotal }(\text { value })} \times 100 \\
& =\frac{9}{10} \times 100 \therefore \text { Producer Accuracy }=81.8 \%
\end{aligned}
$$

In 1990, total number of points was 50 and found total correct points were 49 and errors 1 :

Overall Accuracy $=\frac{\text { Number of total correct points }(\text { value })}{\text { Thenumber of points }(\text { value })} \times 100$ $=\frac{45}{50} \times 100$

$=0.95 \times 100$

$\therefore$ Overall Accuracy $=95 \%$

Kappa coefficient is calculated using Eq. 5 for 1990:

$$
\begin{aligned}
& K=\frac{N \sum_{i=1}^{n} x_{i i}-\sum_{i=1}^{r}\left(x_{i+} \times x_{+i}\right)}{N^{2}-\sum_{i=1}^{r}\left(x_{i i} \times x_{+i}\right)} \times 100 \\
& K=\frac{[(50 \times 45)-\{(10 \times 11)+(10 \times 9)+(10 \times 9)+(10 \times 11)+(10 \times 10)\}]}{\left[\left(50^{2}-(10 \times 11)+(10 \times 9)+(10 \times 9)+(10 \times 11)+(10 \times 10)\right)\right]} \times 100 \\
& K=\frac{2250-(1100+90+90+110+100)}{2500-(1100+90+90+110+100)} \times 100 \\
& K=\frac{(2250-500)}{(2500-500)} \times 100 \\
& K=\frac{1750}{2000} \times 100 \\
& \therefore \text { Kappa coefficient }, K=87.5 \%
\end{aligned}
$$

According to this process, here calculated data of 2000, 2010 and 2019 and that's are shown in the Table 3.

Therefore, according to the process of accuracy assessment of the study, the calculated data of the year 1990, 2000, 2010 and 2019 was accurate Table 3.

\section{Discussion}

The study area is highly vulnerable to natural causalities due to its geographical location (Paul and Dutt, 2010; Alam and Collins, 2010). Land use and land cover 
changing patterns of Bangladesh from 1990 to 2019 were presented here Table 2 and Fig. 3. This study is the first that attempted to combine both techniques and analysis of land cover changes based on supervised classification. This research identifie the land cover changes of Bangladesh in different periods using supervised classification in ArcMap software. Hadeel et al. (2009) were showing the application of remote sensing and GIS for LULC change using supervised classification in June 2009. In Northern Australia, mapping of land covers a comparison of objective oriented and pixel-based classification methods are developed using this process (Whiteside and Ahmad, 2005). However, there have lots of papers that reported the use of supervised classification to detect land cover changes such as Tirupati, India 2013, western Nile delta of Egypt 2011, Southern Appalachian Mountains 2003, South Africa 2007 etc. (Mallupattu et al., 2013; El-Kawy et al., 2011).

In this study, the land cover has classified into five parts (waterbody, forest, urban area, barren soil and vegetation cover). In this study, the calculated waterbody has decreased $3.53 \%$ from 1990 to 2019 Table 2 and Fig. 3. Rai et al. (2017) and his colleague were found permanent wetlands decreased from 4.15 to $1.16 \%$ between 1967 and 2010 in their research paper in 2017. Sundarbans is located in the southeast area of Bangladesh (Islam and Gnauck, 2009; Chatterjee et al., 2015; Mukhopadhyay et al., 2006). Bangladesh forest area is classified as a hill, Sal and mangrove forest based on topographic setting (Alam et al., 2008; Abdullah et al., 2015; Masum et al., 2008). Over the pastime, the forest has been decreasing (Biswas and Choudhury, 2007; Mondal and Debnath, 2017; Iftekhar and Saenger, 2008). Forest cover change has primarily been observed using remotely sensed data for supervised analysis. $3.86 \%$ forest area has decreased in the study area from 1990 to 2019 Table 2 and Fig. 3. Raj et al. (2017) have found $6.2 \%$ of forest area decreased $\left(9054 \mathrm{Km}^{2}\right)$ over the past 85 years from 1930 to 2015 . Hasan et al. (2013) also have found that total forest cover was 12.11, 9.02 and $9.84 \%$ in 1976 , 2000 and 2010 (Hasan et al., 2013). Nevertheless, evaluated that forest area was not changed significantly (8820 to $8840 \mathrm{Km}^{2}$ ) between 1990 and 2000. Moreover, diachronic spatial and non-spatial studies of forest area changes have found that LULC was conducted with different factors over time (Biswas and Choudhury, 2007). Various causes of forest cover deterioration have included; poverty, overpopulation growth, taboo felling, enhancement of agricultural land and lack of appropriate policy and implementation of policy (Lambin et al., 2001; Hansen et al., 2013; Hanewinkel et al., 2013). Spatial patterns of land cover exhibited that urban growth followed certain superintendent between the $2000 \mathrm{~s}$ and $2010 \mathrm{~s}$ depending on the ground elevation (Rai et al., 2017).
Bangladesh has suffered quickly LULC due to speedy population growth and urbanization that resulted from severe contractions in agricultural land (Chakravarty et al., 2012). In this study, the urban area has increased $5.18 \%$ from 1990 to 2019 Table 2 and Fig. 3. However, Hasan et al. (2013) also found that the urban area increased from 474.95 to $876.16 \mathrm{Km}^{2}$ between 2000 and 2010 (Hanewinkel et al., 2013). Barren soil has not significantly changed from 1990 to 2019 according to this study Table 2 and Fig. 3. The first 20 years 1990 to 2010 vegetation area was increased almost $3.36 \%$ but from 2010 to 2019 this area has decreased $0.9 \%$ Table 2 and Fig. 3.

\section{Conclusion}

Land is an important natural resource for our life. Monitoring LULC changes can help to take planning and implementation step to save land cover. The study take the advantage of Landsat TM 4-5 and 8 OLI/TIRS satellite images and ArcGIS software techniques to quantify and calculate the land cover change in Bangladesh from 1990 to 2019. Land use change has a significant negative impact on the society and environment of this study area. Highly development of urban area are created the shortage of agricultural land, vegetation and forest. Agricultural, vegetation and forest area were decreased due to increasing residential area and people's livelihood pattern changed with this trend of land use change. Farmers and fishing engage themselves in small business, auto rickshaw driving and such other jobs. Farmers were used hybrid seeds and pesticides to increase their productivity and it creates environmental pollution. Waterbody and forest have changed into urban area cause of overpopulation and development. Waterbody also has filled up for cultivation and urbanization purposes. Trees are cut down for the fulfilment of the infrastructure needs and fuel. GIS and RS was used to process and analysed the data and finally create the map. Research found that changes happened in urban area, forest and vegetation cover and the percentage is shown in Fig. 3 and Table 2 respectively. These changes are shown human impacts on the study area. Results provide vital information on changing scenario of LULC to the line departments. Study provides some recommendation for proper land use and land cover planning and management:

- District and Upazila land use management strategy should be taken up in order to sustainable development, planning and management of LULC

- Government and different NGOs should take steps to provide training about the impact of land use and land cover change

- Community empowered resource management activity should be increased

- Alternative livelihood pattern and its involvement should be increased 
Furthermore, the land use management policy of Bangladesh needs to be reconsidered and implement multi-disciplinary research for development of sustainable LULC change management strategy.

\section{Acknowledgement}

The research team would like to extend the grateful appreciation to Almighty Allah and is very much grateful and acknowledges the funding support from Research and Training Center (RTC), PSTU. Special thanks and gratitude to Patuakhali Science and Technology University administration for funding us which makes it possible to conduct this research. The research team is highly appreciated the all authors for their enormous priceless effort to make this research successful.

\section{Author's Contributions}

Md. Mahmudul Hasan and Rashidul Islam: Research proposal writing; designing for research project implementation; questionnaire development; making guideline for quality data collection; data processing and analyzing; data interpretation; report writing, finalization of the article, reviewing the article.

Md. Saifur Rahman and Md. Ibrahim: Helped in questionnaire development; data processing and analyzing; report writing.

Md. Shamsuzzoha and Ruma Khanam: Helped in report writing and reviewing.

A. K. M. Mostafa Zaman: Helped in proposal writing, making guideline for quality data collection; data interpretation; finalization of the article, reviewing the article.

\section{Ethics}

Authors followed standard protocols in the entire research approach from research design to reporting.

\section{References}

EL-Kawy, O. R., Rød, J. K., Ismail, H. A., \& Suliman, A. S. (2011). Land use and land cover change detection in the western Nile delta of Egypt using remote sensing data. Applied Geography, 31(2), 483-494.

https://doi.org/10.1016/j.apgeog.2010.10.012

Abdullah, H. M., Mahboob, M. G., Rahman, M. M., \& Ahmed, T. (2015). Monitoring natural Sal forest cover in Modhupur, Bangladesh using temporal Landsat imagery during 1972-2015. International Journal Environmental, 5(1), 1-7. http://www.binbd.com/benjp/ije/IJEvol05no01/ije 050101.pdf
Alam, E., \& Collins, A. E. (2010). Cyclone disaster vulnerability and response experiences in coastal Bangladesh. Disasters, 34(4), 931-954. https://doi.org/10.1111/j.1467-7717.2010.01176.x

Alam, M., Furukawa, Y., Sarker, S. K., \& Ahmed, R. (2008). Sustainability of Sal (Shorea robusta) forest in Bangladesh: past, present and future actions. International Forestry Review, 10(1), 29-37. https://doi.org/10.1505/ifor.10.1.29

Aplin, P., Atkinson, P. M., \& Curran, P. J. (1999). Fine spatial resolution simulated satellite sensor imagery for land cover mapping in the United Kingdom. Remote sensing of Environment, 68(3), 206-216. https://doi.org/10.1016/S0034-4257(98)00112-6

Biswas, S. R., \& Choudhury, J. K. (2007). Forests and forest management practices in Bangladesh: the question of sustainability. International Forestry Review, 9(2), 627-640. https://doi.org/10.1505/ifor.9.2.627

Chakravarty, S., Ghosh, S. K., Suresh, C. P., Dey, A. N., \& Shukla, G. (2012). Deforestation: causes, effects and control strategies. Global Perspectives on Sustainable Forest Management, 1, 1-26. https://doi.org/10.5772/33342

Chatterjee, N., Mukhopadhyay, R., \& Mitra, D. (2015). Decadal changes in shoreline patterns in Sundarbans, India. http://drs.nio.org/drs/handle/2264/4847

Chavez, P., Sides, S. C., \& Anderson, J. A. (1991). Comparison of three different methods to merge multiresolution and multispectral data- Landsat TM and SPOT panchromatic. Photogrammetric Engineering and Remote Sensing, 57(3), 295-303. https://www.asprs.org/wp-

content/uploads/pers/1991journal/mar/1991_mar_29 5-303.pdf

Congalton, R. G. (1991). A review of assessing the accuracy of classifications of remotely sensed data. Remote Sensing of Environment, 37(1), 35-46. https://doi.org/10.1016/0034-4257(91)90048-B

Crosta, A. P., \& Moore, J. M. (1989). Geological mapping using Landsat thematic mapper imagery in Almeria Province, South-east Spain. International Journal of Remote Sensing, 10(3), 505-514. https://www.tandfonline.com/doi/abs/10.1080/0143 1168908903888

Cuervo-Cazurra, A., \& Genc, M. (2008). Transforming disadvantages into advantages: Developing-country MNEs in the least developed countries. journal of International Business Studies, 39(6), 957-979. https://doi.org/10.1057/palgrave.jibs.8400390

Dwivedi, R. S., \& Rao, B. R. M. (1992). The selection of the best possible Landsat TM band combination for delineating salt-affected soils. International Journal of Remote Sensing, 13(11), 2051-2058. https://doi.org/10.1080/01431169208904252 
Elhag, M. (2017). Consideration of landsat-8 Spectral band combination in typical mediterranean forest classification in Halkidiki, Greece. Open Geosciences, 9(1), 468-479. https://doi.org/10.1515/geo-2017-0036

Eva, H. D., Belward, A. S., De Miranda, E. E., Di Bella, C. M., Gond, V., Huber, O., ... \& Fritz, S. (2004). A land cover map of South America. Global Change Biology, 10(5), 731-744. https://doi.org/10.1111/j.1529-8817.2003.00774.x

Faisal, I. M., \& Parveen, S. (2004). Food security in the face of climate change, population growth and resource constraints: implications for Bangladesh. Environmental Management, 34(4), 487-498. https://doi.org/10.1007/s00267-003-3066-7

Fung, T., \& LeDrew, E. (1988). For change detection using various accuracy. Photogramm Eng Remote Sens, 54(10), 1449-1454. http://www.asprs.org/wpcontent/uploads/pers/1988journal/oct/1988_oct_144 9-1454.pdf

Gutman, G., Byrnes, R. A., Masek, J., Covington, S., Justice, C., Franks, S., \& Headley, R. (2008). Towards monitoring land-cover and land-use changes at a global scale: The Global Land Survey 2005. Photogrammetric Engineering and Remote Sensing, 74(1), 6-10. https://pubs.er.usgs.gov/publication/70156428

Hadeel, A., Jabbar, M., \& Chen, X. (2009). Application of remote sensing and GIS to the study of land use/cover change and urbanization expansion in Basrah province, southern Iraq. Geo-spatial Information Science, 12(2), 135-141. https://doi.org/10.1007/s11806-009-0244-7

Hanewinkel, M., Cullmann, D. A., Schelhaas, M. J., Nabuurs, G. J., \& Zimmermann, N. E. (2013). Climate change may cause severe loss in the economic value of European forest land. Nature Climate Change, 3(3), 203-207. https://doi.org/10.1038/nclimate1687

Hansen, M. C., Potapov, P. V., Moore, R., Hancher, M., Turubanova, S. A., Tyukavina, A., ... \& Townshend, J. (2013). High-resolution global maps of 21stcentury forest cover change. Science, 342(6160), 850-853. https://doi.org/10.1126/science.1244693

Hasan, M. N., Hossain, M. S., Islam, M. R., Bari, M. A., Karim, D., \& Rahman, M. Z. (2013). Trends in the availability of agricultural land in Bangladesh. Soil Resource Development Institute (SERDI), Ministry of Agriculture, Bangladesh, Dhaka. http://www. nfpcsp. org/agridrupal/sites/default/files/Trends-inthe-availability-ofagricultural-land-in-BangladeshSRDI-Supported-by-NFPCSP-FAO
Hood, G. A., \& Bayley, S. E. (2008). Beaver (Castor canadensis) mitigate the effects of climate on the area of open water in boreal wetlands in western Canada. Biological Conservation, 141(2), 556-567. https://doi.org/10.1016/j.biocon.2007.12.003

Hossain, M. S., Arshad, M., Qian, L., Kächele, H., Khan, I., Islam, M. D. I., \& Mahboob, M. G. (2020). Climate change impacts on farmland value in Bangladesh. Ecological Indicators, 112, 106181. https://doi.org/10.1016/j.ecolind.2020.106181

Iftekhar, M. S., \& Saenger, P. (2008). Vegetation dynamics in the Bangladesh Sundarbans mangroves: a review of forest inventories. Wetlands Ecology and Management, 16(4), 291-312. https://doi.org/10.1007/s11273-007-9063-5

Islam, S. N., \& Gnauck, A. (2009). Threats to the Sundarbans mangrove wetland ecosystems from transboundary water allocation in the Ganges basin: A preliminary problem analysis. International Journal of Ecological Economics \& Statistics, 13(W09), 64-78. https://citeseerx.ist.psu.edu/viewdoc/download?doi= 10.1.1.872.5987\&rep=rep1\&type $=$ pdf

Jain, A., Saini, V., \& Veer Kohli, D. (2013). Edible transgenic plant vaccines for different diseases. Current Pharmaceutical Biotechnology, 14(6), 594-614. https://doi.org/10.2174/138920101131400225

Jensen, J. R., \& Cowen, D. C. (1999). Remote sensing of urban/suburban infrastructure and socio-economic attributes. Photogrammetric engineering and remote sensing, 65, 611-622. http://www.asprs.org/wpcontent/uploads/pers/99journal/may/1999_may_611 -622.pdf

Lambin, E. F., Turner, B. L., Geist, H. J., Agbola, S. B., Angelsen, A., Bruce, J. W., ... \& Xu, J. (2001). The causes of land-use and land-cover change: moving beyond the myths. Global Environmental Change, 11(4), 261-269. https://doi.org/10.1016/S09593780(01)00007-3

Leprince, S., Barbot, S., Ayoub, F., \& Avouac, J. P. (2007). Automatic and precise orthorectification, coregistration and subpixel correlation of satellite images, application to ground deformation measurements. IEEE Transactions on Geoscience and Remote Sensing, 45(6), 1529-1558. https://doi.org/10.1109/TGRS.2006.888937

López, E., Bocco, G., Mendoza, M., \& Duhau, E. (2001). Predicting land-cover and land-use change in the urban fringe: a case in Morelia city, Mexico. Landscape and Urban Planning, 55(4), 271-285. https://doi.org/10.1016/S0169-2046(01)00160-8

Lucas, R., Rowlands, A., Brown, A., Keyworth, S., \& Bunting, P. (2007). Rule-based classification of multitemporal satellite imagery for habitat and agricultural land cover mapping. ISPRS Journal of Photogrammetry and Remote Sensing, 62(3), 165-185. https://doi.org/10.1016/j.isprsjprs.2007.03.003 
Magesh, N. S., \& Ch, N. (2012). A GIS based automated extraction tool for the analysis of basin morphometry. Bonfring International Journal of Industrial Engineering and Management Science, 2(Special Issue Special Issue on Geospatial Technology Development in Natural Resource and Disaster Management), 32-35. http://www.journal.bonfring.org/abstract.php?id=3\& archiveid $=144$

Mallupattu, P. K., \& Sreenivasula Reddy, J. R. (2013). Analysis of land use/land cover changes using remote sensing data and GIS at an Urban Area, Tirupati, India. The Scientific World Journal, 2013. https://doi.org/10.1155/2013/268623

Masum, K. M., Alam, M. S., \& Abdullah-Al-Mamun, M. M. (2008). Ecological and economical significance of homestead forest to the household of the offshore island in Bangladesh. Journal of Forestry Research, 19(4), 307-310. https://doi.org/10.1007/s11676-008-0055-y

Mondal, S. H., \& Debnath, P. (2017). Spatial and temporal changes of Sundarbans reserve forest in Bangladesh. Environment and Natural Resources Journal, 15(1), 51-61. https://ph02.tcithaijo.org/index.php/ennrj/article/view/80744

Mukhopadhyay, S. K., Biswas, H. D. T. K., De, T. K., \& Jana, T. K. (2006). Fluxes of nutrients from the tropical River Hooghly at the land-ocean boundary of Sundarbans, NE Coast of Bay of Bengal, India. Journal of Marine Systems, 62(1-2), 9-21. https://doi.org/10.1016/j.jmarsys.2006.03.004

Mwaniki, M. W., Moeller, M. S., \& Schellmann, G. (2015). A comparison of Landsat 8 (OLI) and Landsat 7 (ETM+) in mapping geology and visualising lineaments: A case study of central region Kenya. International Archives of the Photogrammetry, Remote Sensing \& Spatial Information Sciences. https://doi.org/10.5194/isprsarchives-XL-7-W3-8972015

Ojima, D. S., Galvin, K. A., \& Turner, B. L. (1994). The global impact of land-use change. BioScience, 44(5), 300-304. https://doi.org/10.2307/1312379

Paul, B. K., \& Dutt, S. (2010). Hazard warnings and responses to evacuation orders: the case of Bangladesh's cyclone Sidr. Geographical Review, 100(3), 336-355. https://doi.org/10.1111/j.19310846.2010.00040.x

Rai, R., Zhang, Y., Paudel, B., Li, S., \& Khanal, N. R. (2017). A synthesis of studies on land use and land cover dynamics during 1930-2015 in Bangladesh. Sustainability, $\quad 9(10), \quad 1866$. https://doi.org/10.3390/su9101866

Ramírez-Villegas, J., \& Bueno Cabrera, A. (2009). Working with climate data and niche modeling: I. Creation of bioclimatic variables. https://cgspace.cgiar.org/handle/10568/90732
Rawat, J. S., \& Kumar, M. (2015). Monitoring land use/cover change using remote sensing and GIS techniques: A case study of Hawalbagh block, district Almora, Uttarakhand, India. The Egyptian Journal of Remote Sensing and Space Science, 18(1), 77-84. https://doi.org/10.1016/j.ejrs.2015.02.002

Riggio, J., Kija, H., Masenga, E., Mbwilo, F., Van de Perre, F., \& Caro, T. (2018). Sensitivity of Africa's larger mammals to humans. Journal for Nature Conservation, 43, 136-145. https://doi.org/10.1016/j.jnc.2018.04.001

Riggio, S. S., \& Ndambuki, J. M. (2017). Accuracy assessment of land use/land cover classification using remote sensing and GIS. International Journal of Geosciences, $8(04), 611$. https://doi.org/10.4236/ijg.2017.84033

Sikarwar, A., \& Chattopadhyay, A. (2016). Change in land use-land cover and population dynamics: A town-level Study of Ahmedabad city sub-District of Gujarat. International Journal of Geomatics and Geosciences, $\quad 7(2), \quad 225-234$. https://www.academia.edu/download/53442229/My _paper_IJGGS.pdf

Su, X., He, C., Feng, Q., Deng, X., \& Sun, H. (2010). A supervised classification method based on conditional random fields with multiscale region connection calculus model for SAR image. IEEE Geoscience and Remote Sensing Letters, 8(3), 497-501. https://doi.org/10.1109/LGRS.2010.2089427

Tamouk, J., Lotfi, N., \& Farmanbar, M. (2013). Satellite image classification methods and Landsat 5TM Bands. arXiv preprint arXiv:1308.1801. https://arxiv.org/abs/1308.1801

Tilahun, A., \& Teferie, B. (2015). Accuracy assessment of land use land cover classification using Google Earth. American Journal Environmental Prot, 4(4), 193-198.

https://doi.org/10.11648/j.ajep.20150404.14

Tucker, C. J., Townshend, J. R., \& Goff, T. E. (1985). African land-cover classification using satellite data. Science, 227(4685), 369-375. https://doi.org/10.1126/science.227.4685.369

Unger Holtz, T. S. (2007). Introductory digital image processing: A remote sensing perspective. https://doi.org/10.2113/gseegeosci.13.1.89

Weng, Q. (2002). Land use change analysis in the Zhujiang Delta of China using satellite remote sensing, GIS and stochastic modelling. Journal of Environmental Management, 64(3), 273-284. https://doi.org/10.1006/jema.2001.0509 
Whiteside, T., \& Ahmad, W. (2005, September). A comparison of object-oriented and pixel-based classification methods for mapping land cover in northern Australia. In Proceedings of SSC2005 Spatial intelligence, innovation and praxis: The national biennial Conference of the Spatial Sciences Institute (pp. 1225-1231).

Xiubin, L. (1996). A review of the international researches on land use/land cover change [J]. Acta Geographica Sinica,

6. https://en.cnki.com.cn/Article_en/CJFDTotalDLXB606.008.htm
Yang, X., \& Lo, C. P. (2002). Using a time series of satellite imagery to detect land use and land cover changes in the Atlanta, Georgia metropolitan area. International Journal of Remote Sensing, 23(9), 1775-1798. https://doi.org/10.1080/01431160110075802

Zha, Y., Gao, J., \& Ni, S. (2003). Use of normalized difference built-up index in automatically mapping urban areas from TM imagery. International Journal of Remote Sensing, 24(3), 583-594. https://doi.org/10.1080/01431160304987 